\title{
Enhancing the Decolorizing and Degradation Ability of Bacterial Consortium Isolated from Textile Effluent Affected Area and Its Application on Seed Germination
}

\author{
Rashid Mahmood, ${ }^{1}$ Faiza Sharif, ${ }^{1}$ Sikander Ali, ${ }^{2}$ and Muhammad Umar Hayyat ${ }^{1}$ \\ ${ }^{1}$ Sustainable Development Study Centre, GC University, Lahore 54000, Pakistan \\ ${ }^{2}$ Institute of Industrial Biotechnology, GC University, Lahore 54000, Pakistan \\ Correspondence should be addressed to Rashid Mahmood; rashid_mehmood33@yahoo.com
}

Received 14 July 2014; Revised 24 September 2014; Accepted 3 October 2014

Academic Editor: Wendong Tao

Copyright (c) 2015 Rashid Mahmood et al. This is an open access article distributed under the Creative Commons Attribution License, which permits unrestricted use, distribution, and reproduction in any medium, provided the original work is properly cited.

\begin{abstract}
A bacterial consortium BMP1/SDSC/01 consisting of six isolates was isolated from textile effected soil, sludge, and textile effluent from Hudiara drain near Nishat Mills Limited, Ferozepur Road, Lahore, Pakistan. It was selected because of being capable of degrading and detoxifying red, green, black, and yellow textile dyes. The $\mathrm{pH}$ and supplements were optimized to enhance the decolorization ability of the selected consortium. The results indicated that decolorizing ability of consortium for the red, green, black, and yellow dyes was higher as compared to individual strains. The consortium was able to decolorize $84 \%, 84 \%, 85 \%, 85 \%$, and $82 \%$ of $200 \mathrm{ppm}$ of red, green, black, yellow, and mixed dyes within $24 \mathrm{~h}$ while individual strain required $72 \mathrm{~h}$. On supplementing urea, the consortium decolorized $87,86,89,86$, and $83 \%$, respectively, while on supplementing sodium chloride the consortium decolorized $93,94,93,94$, and $89 \%$ of red, green, black, yellow, and mixed dyes, respectively, which was maximum while in the presence of ascorbic acid and ammonium chloride it showed intermediate results. The effect of untreated and treated dyes was investigated on Zea mays L. (maize) and Sorghum vulgare Pers. (sorghum). This study will help to promote an efficient biotreatment of textile effluents.
\end{abstract}

\section{Introduction}

Among the various industrial sectors, the textile and paper industries are especially problematic since they generate significant quantities of wastewater that may have detrimental impacts when released into the environment without any treatment. The environmental problems associated with textile activities are caused mainly by the extensive use of dyes [1]. A great number of these compounds are recalcitrant and have carcinogenic or mutagenic properties. Azo dyes are mostly used in the textile industry due to their extensive variety of color shades and brilliant colors but they are recalcitrant xenobiotics $[2,3]$. Ozonation, photooxidation, electrocoagulation, adsorption, activated carbon, froth flotation, reverse osmosis, ion exchange, membrane filtration, and flocculation are applied for color removal from textile effluents [4]. These physicochemical methods are less efficient, have high operational cost, and produce wastes, which are difficult to dispose of. Reduction of color from dye bearing wastewater is a complex problem because of difficulty in treating such wastewaters by conventional treatment methods [5].

Bacteria can be used to remove dyes; some new bacterial strains capable of decolorizing a broad spectrum of dyes have also been isolated and characterized. Though many works have been done on the decolorization of dye by bacteria, work is still required to isolate new bacteria capable of degrading a wide range of structurally different dyes. The study of their physiological characteristics and underlying mechanisms of dye biodegradation at specific temperature and $\mathrm{pH}$ is also very important $[3,6,7]$. Various bacterial strains may attack dye molecule at different positions or may use decomposed products produced by another strain for further decomposition [8]. Microbial systems have already been described for remediation of metals and dye contaminated soil and water [9]. The method of microbial degradation of colors involves the reductive cleavage of azo bonds $(-\mathrm{N}=\mathrm{N}-)$ with 
the help of azo reductase in anaerobic conditions resulting in the formation of colorless solutions. The effectiveness of microbial decolorization depends on the adaptability and the activity of selected microorganisms [10]. Microbial consortia have been widely used in cleanup of a number of pollutants in laboratory and field bioremediation studies. It is generally thought that microbial consortia are more effective than pure cultures in biodegradation. This is possibly because broader enzymatic capacity is achieved and the formation of toxic intermediate metabolites is counteracted by the selection of these dead end products formed mainly by cometabolism processes. Bacteria express their full capacity to degrade the pollutants in optimal conditions. Temperature, $\mathrm{pH}$, and supplements have great influence on their growth $[11,12]$.

Phytotoxicity is the most studied parameter amongst the toxicity assays. Genotoxic and cytotoxic effects of textile effluent on the plant root cells were previously demonstrated but some other toxic effects of these effluents on plants are yet to be studied [17]. An assessment of the ecological impact of the environmental pollutants on the plant populations is of great importance as plants are important commercial products and are consumed by humans. Moreover, plants may be used as biosensors of genetic toxicity of the environmental pollutants [13]. There is still room for research to unravel the potential of indigenous microbes for the rehabilitation of the natural resources. Researchers had already worked on the decolorizing ability of bacteria using separate dyes. However, there is a need to treat mixture of dyes as dyes are mostly present in a mixture form in the textile effluent. In this study, isolation and screening of the indigenous bacteria were carried out from textile effluent contaminated sites and a bacterial consortium was developed to reduce the concentration of mixture of dyes. The effect of untreated and treated dyes was investigated on the germination of Zea mays L. (Maize) and Sorghum vulgare Pers. (Sorghum). This study will help to promote an effective biotreatment of textile effluents.

\section{Materials and Methods}

2.1. Sample Collection. Wastewater, sludge, and effected soil samples were collected in screw-capped sterilized bottles for the isolation of bacterial strains from Hudiara drain near Nishat Mills Limited, Ferozepur Road, Lahore 54600, Pakistan One sample of soil, four samples of sludge, and four samples of wastewater were collected from 0, 5, 500, and 1000 meters away from the main outlet [18].

\subsection{Isolation, Screening, and Identification of the Indigenous} Bacteria. The isolation of degrading and detoxifying indigenous bacteria was carried out through serial dilution method on nutrient agar medium at $37^{\circ} \mathrm{C}$ for $24 \mathrm{~h}$ incubation $[13,19]$. Isolated bacterial strains were screened out by incubating them on nutrient agar medium containing red (Carmine Red), green (Light Green), black (Eriochrome Black T), and yellow (Metanil Yellow) dyes using $200 \mathrm{ppm}$ of each. The stock cultures of screened bacterial isolates were maintained routinely on the nutrient agar medium and stored at $4^{\circ} \mathrm{C}$.
The screened bacterial strains were identified based on morphological, biochemical, and physiological properties using the protocol given in Bergey's Manual of Determinative Bacteriology [20].

2.3. Development of Bacterial Consortium. The isolates for the consortium development were selected based on criteria: ability to degrade the dyes efficiently (above 60\%) and rapidly (within 3 days) and also ability to degrade red, green, black, and yellow dyes. A consortium was developed using combinations of six isolates. A loopful of the selected isolates was individually inoculated for $24 \mathrm{~h}$ at $37^{\circ} \mathrm{C}$ to form a consortium [21].

\subsection{Determination of Optimal Growth Conditions for Bacterial} Consortium. The bacterial isolates were optimized at $\mathrm{pH}$ values $6,6.5,7,7.5,8$, and 8.5 and at temperatures $27,32,37$, 42 , and $47^{\circ} \mathrm{C}$ on nutrient broth having red, green, black, and yellow dyes using $200 \mathrm{ppm}$ of each [22].

2.5. Decolorization. Decolorization ability of bacterial isolates and developed consortium was analyzed by using spectrophotometer (SpectroScan 80D UV-VIS) at optimum wavelengths $510 \mathrm{~nm}$ for red and black, $410 \mathrm{~nm}$ for yellow, $340 \mathrm{~nm}$ for green dyes, and $520 \mathrm{~nm}$ for mixed dyes. All the decolorization experiments were performed in triplicate on nutrient broth with and without supplements (starch, urea, sodium chloride, ammonium chloride, and ascorbic acid) at $37^{\circ} \mathrm{C}$ for $24 \mathrm{~h}$ incubation. The decolorization activity was expressed in terms of decolorization \% using the formula of Cheriaa et al. [14]:

$$
\text { Decolorization } \%=\frac{A t_{0}-A t_{f}}{A t_{0}} \times 100,
$$

where $A t_{0}$ is initial absorbance and $A t_{f}$ is absorbance at incubation time.

2.6. Phytotoxicity Studies. In order to assess the toxicity dyes and degraded compound of dye, phytotoxicity tests were performed on Zea mays L. CV C1415 (maize) and Sorghum vulgare Pers. CV SSG5000 (sorghum). The degraded products of red, green, black, and yellow dyes were extracted and dissolved in $10 \mathrm{~mL}$ distilled water for phytotoxicity tests. The phytotoxicity tests were carried out on seeds of maize and sorghum (common agricultural crops of Pakistan). The study was carried out at room temperature (20 seeds of each) by watering $5 \mathrm{~mL}$ of red, green, black, and yellow dyes. Control set was carried out using irrigation water at the same time. Germination (\%), plumule, and radicle lengths were recorded after 7 days [10].

\section{Results}

3.1. Isolation, Screening, and Identification of Dye Decolorizing Bacterial Strains. During isolation process a total of 76 bacterial colonies were observed. From those colonies 21 bacterial strains were isolated as most of the colonies were 

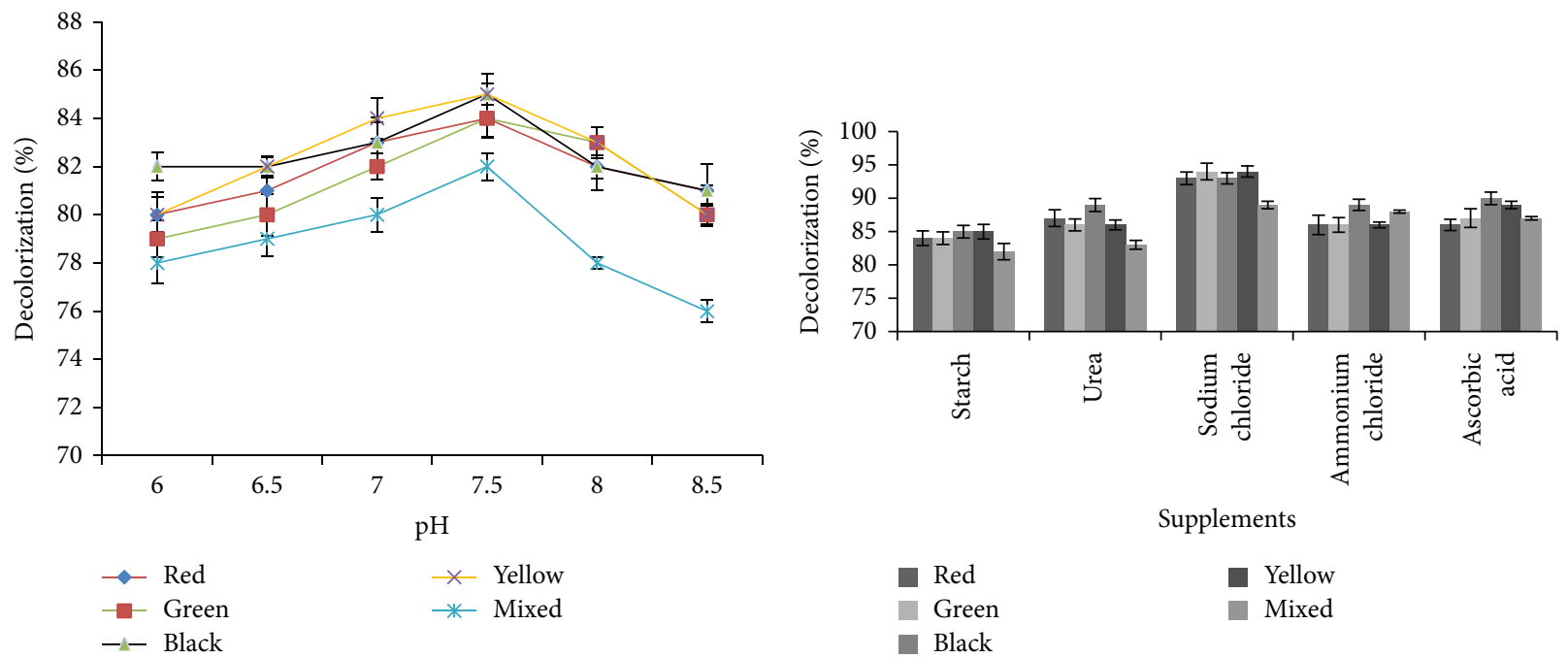

(a)

(b)

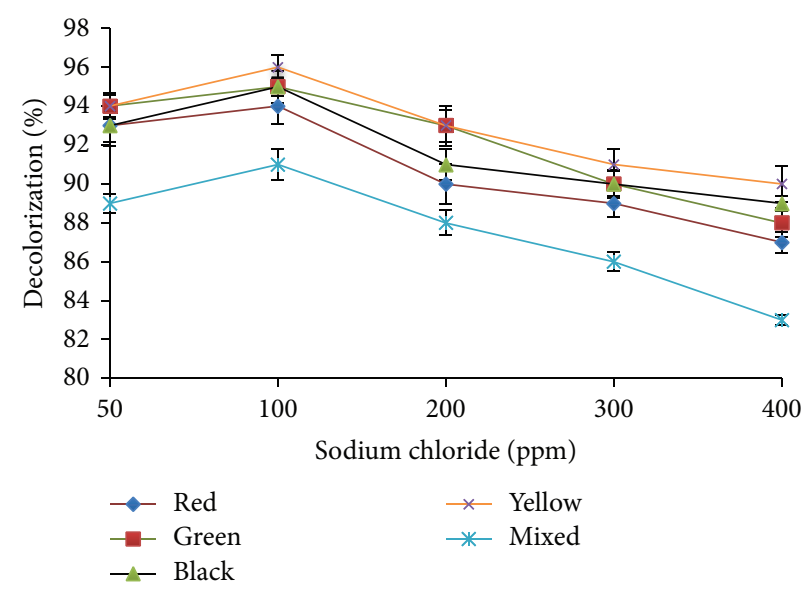

(c)

FIGURE 1: Effect of pH (a), supplements (b), and sodium chloride (c) on decolorizing ability of consortium.

morphologically similar. The isolates $1,3,5,7,9$, and 20 were screened on basis of the ability to degrade the dyes efficiently more than 60\%, within 3 days at 50,100, 150, and $200 \mathrm{ppm}$ of red, green, yellow, and black dyes. These isolates also exhibited ability to degrade mixture of red, green, black, and yellow dyes. The isolates were identified as Bacillus subtilis (Isolate 20), Bacillus cereus (Isolate 3), Bacillus mycoides (Isolate 1), Bacillus sp. (Isolate 5), Pseudomonas sp. (Isolate 9), and Micrococcus sp. (Isolate 7) by standard physiological, morphological, and biochemical tests using the protocol set in Bergey's Manual of Determinative Bacteriology [20].

3.2. Development of Consortium and Decolorization of Textile Dyes. Consortium BMP1/SDSC-01 was developed. It was consisted of Bacillus subtilis, Bacillus cereus, Bacillus mycoides, Bacillus sp., Micrococcus sp., and Pseudomonas sp. It was observed that isolates alone and in consortium represent an inexpensive tool for the degradation of dyes present in textile effluents. This tool was tested in the present study by examining the decolorization \% of red, green, black, and yellow dyes by individual isolates and consortium. It is clearly shown (Tables $1(\mathrm{a})$ and $1(\mathrm{~b})$ ) that pure culture of six isolates decolorized the red dye from $74 \%$ to $79 \%$ while the consortium decolorized $84 \%$, which is due to accumulative effect of the bacteria present in the consortium. The green dye was decolorized by individual isolate from $75 \%$ to $79 \%$ and is enhanced by the consortium up to $84 \%$. The black dye was decolorized up to $85 \%$ by consortium, while individual strains show maximum efficiency of $79 \%$. Similarly yellow dye decolorization by individual strains was less $(74-79 \%)$ than the consortium $(85 \%)$. The consortium performed decolorization of red, green, black, yellow, and mixed dyes at $\mathrm{pH} 7.5$ (incubated at $37^{\circ} \mathrm{C}$ ) up to $84,84,85$, 85 , and $82 \%$, respectively. It was noted that decolorization decreased at $\mathrm{pH}$ values 6 and 8.5. The consortium showed maximum decolorization of dyes at temperature $37^{\circ} \mathrm{C}$ and $\mathrm{pH}$ 7.5 (Figure 1).

3.3. Enhancement in the Decolorization Ability of Consortium. The consortium was able to decolorize $200 \mathrm{ppm}$ of red 
TABLE 1: (a) Comparison of dye decolonization by different isolates from textile industry effluent. (b) Formal names and chemical structures of dyes used during decolorization.

(a)

\begin{tabular}{|c|c|c|c|c|c|c|c|c|c|c|}
\hline \multirow{4}{*}{$\begin{array}{l}\text { Sr. } \\
\text { number }\end{array}$} & \multirow{4}{*}{ Dyes } & \multirow{4}{*}{ Chemical class } & \multirow{4}{*}{$\begin{array}{l}\lambda_{\max } \\
\mathrm{nm}\end{array}$} & \multicolumn{7}{|c|}{ Decolonization (\%) } \\
\hline & & & & \multicolumn{7}{|c|}{ Incubation time } \\
\hline & & & & & & & $72 \mathrm{~h}$ & & & $24 \mathrm{~h}$ \\
\hline & & & & $\begin{array}{l}\text { Bacillus } \\
\text { mycoides }\end{array}$ & $\begin{array}{c}\text { Bacillus } \\
\text { cereus }\end{array}$ & $\begin{array}{c}\text { Bacillus } \\
\text { sp. }\end{array}$ & $\begin{array}{l}\text { Pseudomonas } \\
\text { sp. }\end{array}$ & $\begin{array}{l}\text { Micrococcus } \\
\text { sp. }\end{array}$ & $\begin{array}{c}\text { Bacillus } \\
\text { subtilis }\end{array}$ & Consortium \\
\hline 1 & Red & Carmine acid & 510 & 74 & 76 & 75 & 79 & 78 & 77 & 84 \\
\hline 2 & Green & Benzenesulfonate & 340 & 76 & 75 & 79 & 76 & 79 & 78 & 84 \\
\hline 3 & Black & Monoazo & 510 & 73 & 74 & 74 & 77 & 77 & 79 & 85 \\
\hline 4 & Yellow & Monoazo & 410 & 76 & 74 & 77 & 78 & 79 & 79 & 85 \\
\hline
\end{tabular}

(b)

Sr.
number Dyes Formal name

2

Green $\quad$ Light Green

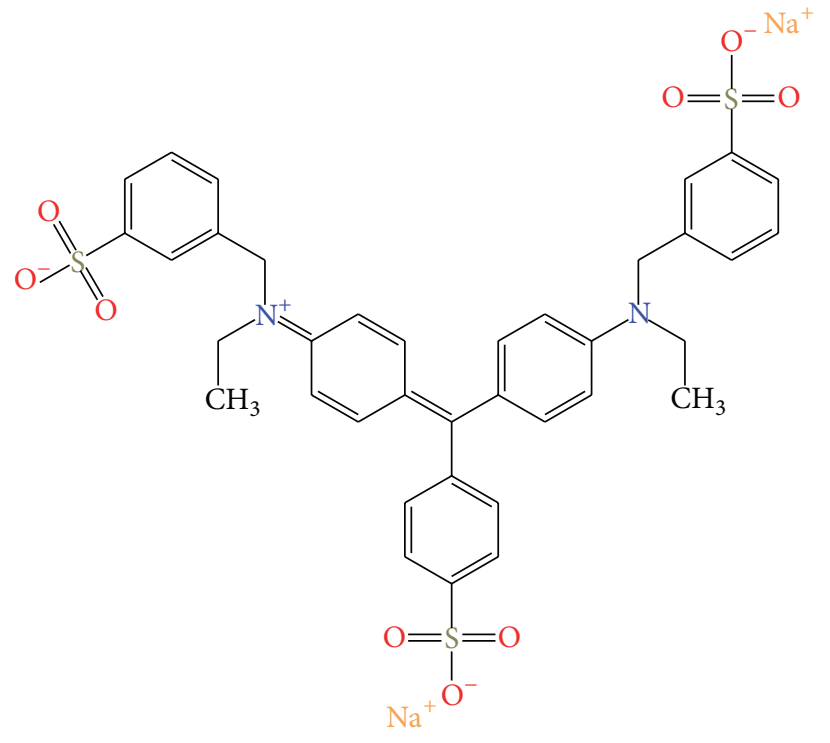

3

Black

Eriochrome Black

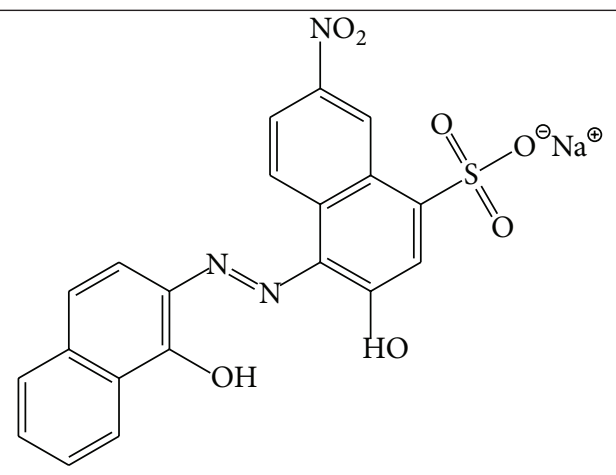


(b) Continued.

\begin{tabular}{llcl}
\hline $\begin{array}{l}\text { Sr. } \\
\text { number }\end{array}$ & Dyes & Formal name & Chemical structure \\
\hline & Yellow & Metanil Yellow
\end{tabular}

TABLE 2: Phytotoxicity test of different treated and untreated textile dyes.

\begin{tabular}{lcccc}
\hline Treatments & Maize & & Sorghum \\
& Plumule $(\mathrm{cm})$ & Radicle $(\mathrm{cm})$ & Plumule $(\mathrm{cm})$ & Radicle $(\mathrm{cm})$ \\
\hline Control (irrigation water) & $20 \pm 0.64$ & $6 \pm 0.96$ & $22 \pm 1.14$ & $6 \pm 0.68$ \\
Red dye & $5 \pm 0.08$ & $2 \pm 0.11$ & $3 \pm 0.22$ & $2 \pm 0.024$ \\
Degraded red dye & $14 \pm 0.79$ & $4 \pm 0.04$ & $7 \pm 0.30$ & $4.2 \pm 0.15$ \\
Green dye & $6.5 \pm 0.59$ & $3 \pm 0.02$ & $4.3 \pm 0.81$ & $2.3 \pm 0.11$ \\
Degraded green dye & $15 \pm 1.3$ & $5 \pm 0.31$ & $7.5 \pm 1.01$ & $5.4 \pm 1.04$ \\
Black dye & $4.5 \pm 0.48$ & $2 \pm 0.040$ & $3.5 \pm 0.38$ & $2.9 \pm 0.12$ \\
Degraded black dye & $12.5 \pm 1.40$ & $4.5 \pm 0.63$ & $7.5 \pm 0.79$ & $4.9 \pm 1.04$ \\
Yellow dye & $5 \pm 0.41$ & $2 \pm 0.027$ & $4.1 \pm 0.52$ & $2.4 \pm 0.28$ \\
Degraded yellow dye & $13 \pm 0.72$ & $5.2 \pm 0.14$ & $7.1 \pm 0.46$ & $5.4 \pm 1.05$ \\
\hline
\end{tabular}

(84\%), green (84\%), black (85\%), yellow (85\%), and mixed dyes $(82 \%)$ within $24 \mathrm{~h}$ without supplements, whereas on supplementing urea the consortium decolorized $87,86,89$, 86 , and $83 \%$, respectively. On supplementing sodium chloride the consortium decolorized $93,94,93,94$, and $89 \%$ of red, green, black, yellow, and mixed dyes within $24 \mathrm{~h}$, respectively, which was maximum. Starch supplement did not affect the decolorization of dyes. Ammonium chloride and ascorbic acid also increased the decolorization. The decolorizing efficiency of consortium for red, green, black, and yellow dyes over a range of $\mathrm{NaCl}$ concentrations (50 ppm to $400 \mathrm{ppm}$ ) was assessed at $37^{\circ} \mathrm{C}$. The results indicated that decolorization was maximum at $100 \mathrm{ppm}$; there was decreasing trend of decolorization at more than $100 \mathrm{ppm} \mathrm{NaCl}$ concentrations (Figure 1).

3.4. Phytotoxicity Studies. The water bodies used for irrigation purposes contain untreated effluent from dyeing industry. This practice is of great environmental concern as it associates with biotic and ecosystem health. Soil fertility is directly and indirectly dependent on irrigation water. Biodegradation of effluent leads to generation of various degradation products. Therefore, it is virtually important to study the toxicity impact of these degradation products on plants [23]. The relative sensitivity of Zea mays L. and Sorghum vulgare Pers. towards the red, green, black, and yellow dyes and its degradation products by consortium were studied. There was $100 \%$ germination in control (irrigated water). The germination of $Z$. mays was inhibited to 37.5, 41,34 , and $39 \%$, when treated with $200 \mathrm{ppm}$ of red, green, black, and yellow dyes, respectively. While the germination of $S$. vulgare was also inhibited to $33,36,34$, and $42 \%$ when treated with $200 \mathrm{ppm}$ of red, green, black, and yellow dyes, respectively. The germination of $Z$. mays was $96,95,96$, and $96 \%$ when treated with degradation products of red, green, black, and yellow dyes, respectively. Similarly the germination $\%$ of S. vulgare was 96, 97, 98, and 97 (Figure 2).

The plumule length and radicle length of Zea mays were $20 \pm 0.64$ and $6 \pm 0.96 \mathrm{~cm}$ and in case of Sorghum vulgare $22 \pm 1.14$ and $6 \pm 0.68 \mathrm{~cm}$, respectively. Plumule and radicle length of $Z$. mays weredrastically affected when treated with $200 \mathrm{ppm}$ of red, green, black, and yellow dyes, which was $5 \pm 0.08,6.5 \pm 0.95,4.5 \pm 0.48$, and $5 \pm 0.41$ and $2 \pm 0.11$, $3 \pm 0.02,2 \pm 0.042$, and $2 \pm 0.027$, respectively. Plumule and radicle length of $S$. vulgare decreased up to $3 \pm 0.22$, $4.3 \pm 0.81,3.5 \pm 0.38$, and $4.1 \pm 0.52$ and $2 \pm 0.024,2.3 \pm 0.11$, $2.9 \pm 0.12$, and $2.4 \pm 0.28$, respectively, when treated with $200 \mathrm{ppm}$ concentration of red, green, black, and yellow dyes. Plumule and radicle length $(\mathrm{cm})$ of $Z$. mays when treated with degradation products of red, green, black, and yellow dyes were $14,15,12$, and 13 and 4,5, 4.5, and 5.2, respectively. Plumule and radicle length $(\mathrm{cm})$ of $S$. vulgare were $7 \pm 0.30$, $7.5 \pm 1.01,7.5 \pm 0.78$, and $7.1 \pm 0.46$ and $4.2 \pm 0.15,4.5 \pm 1.04$, $49 \pm 1.04$, and $5.4 \pm 1.04$, respectively, when treated with degradation products of red, green, black, and yellow dyes (Table 2).

\section{Discussion}

Bacillus subtilis, Bacillus cereus, Bacillus mycoides, Bacillus sp., Micrococcus sp., and Pseudomonas sp. were isolated from effluent, sludge, and effected soil. A consortium BMP1/SDSC01 was developed from these isolates. The consortium had ability to degrade red, green, black, and yellow dyes and the 
TABLE 3: Decolorization rate of different bacterial consortium.

\begin{tabular}{|c|c|c|c|c|}
\hline Sr. number & Consortium/bacteria & $\begin{array}{l}\text { Decolorization } \\
\text { rate }(\mathrm{mg} / \mathrm{h})\end{array}$ & Name of dye & Reported by \\
\hline 1 & Citrobacter sp. CK3 & 5.55 & Reactive Red 180 & Wang et al. [3] \\
\hline 2 & $\begin{array}{l}\text { Consortium GR (Proteus vulgaris andMicrococcus } \\
\text { glutamicus) }\end{array}$ & 1.60 & Azo dye Scarlet R & Saratale et al. [10] \\
\hline 3 & Consortium DAS (3 strains of Pseudomonas sp.) & 0.43 & Reactive Orange 16 & Jadhav et al. [13] \\
\hline 4 & $\begin{array}{l}\text { Consortium CM-4 (Agrobacterium radiobacter, Aeromonas } \\
\text { hydrophila, Bacillus sp., and Sphingomonas paucimobilis) }\end{array}$ & 2.08 & Crystal violet & Cheriaa et al. [14] \\
\hline 5 & $\begin{array}{l}\text { Consortium CM-4 (Agrobacterium radiobacter, Aeromonas } \\
\text { hydrophila, Bacillus sp., and Sphingomonas paucimobilis) }\end{array}$ & 2.08 & Malachite Green & Cheriaa et al. [14] \\
\hline 6 & Bacillus sp. YZU1 & 0.83 & Reactive Black 5 & Wang et al. [15] \\
\hline 7 & Brevibacillus laterosporus MTCC & 0.91 & Golden Yellow HER & Gomare et al. [16] \\
\hline \multirow[t]{4}{*}{8} & $\begin{array}{l}\text { Consortium BMP1/SDSC/01 } \\
\text { (Bacillus mycoides, Bacillus cereus, Bacillus sp., Pseudomonas } \\
\text { sp., Micrococcus sp., and Bacillus subtilis) }\end{array}$ & 7.00 & Red & Present Study \\
\hline & $\begin{array}{l}\text { Consortium BMP1/SDSC/01 } \\
\text { (Bacillus mycoides, Bacillus cereus, Bacillus sp., Pseudomonas } \\
\text { sp., Micrococcus sp., and Bacillus subtilis) }\end{array}$ & 7.00 & Green & Present Study \\
\hline & $\begin{array}{l}\text { Consortium BMP1/SDSC/01 } \\
\text { (Bacillus mycoides, Bacillus cereus, Bacillus sp., Pseudomonas } \\
\text { sp., Micrococcus sp., and Bacillus subtilis) }\end{array}$ & 7.08 & Black & Present Study \\
\hline & $\begin{array}{l}\text { Consortium BMP1/SDSC/01 } \\
\text { (Bacillus mycoides, Bacillus cereus, Bacillus sp., Pseudomonas } \\
\text { sp., Micrococcus sp., and Bacillus subtilis) }\end{array}$ & 7.08 & Yellow & Present Study \\
\hline
\end{tabular}

mixture of all these dyes. Indigenous isolates have the potential to degrade the dye in natural conditions without high input for their growth. Various strains attack dye molecule at different positions and decomposed products are used by another strain for further decomposition [8]. The main advantage of this consortium is due to its heterogeneity. It is developed from bacteria which were isolated from different sources. They worked together and gave better results for the degradation of dyes. The consortium development in the literature shows that all the researchers developed consortium from single source, whereas Mao et al. [12] reported that heterogeneity of the bacterial community; in this way consortium gave better results in degradation/detoxification of dyes (Table 3). Han et al. [24] also isolated the bacteria for decolorization of textile dyes from the different sources.

The consortium exhibited decolorization of red, green, black, yellow, and mixed dyes at $\mathrm{pH} 7.5$ (incubated at $37^{\circ} \mathrm{C}$ ) up to $84,84,85,85$, and $82 \%$, respectively. It is observed that decolorization decreases at $\mathrm{pH}$ values 6 and 8.5 , as the enzymatic system of bacteria is very sensitive to $\mathrm{pH}$. The consortium exhibited maximum decolorization of dyes at temperature of $37^{\circ} \mathrm{C}(\mathrm{pH} 7.5)$. The consortium was capable of decolorization from 27 to $47^{\circ} \mathrm{C}$, but decolorization \% decreased above and below $37^{\circ} \mathrm{C}$. Moosvi et al. [25] and Jain et al. [11] reported a similar finding showing maximum decolorization at $\mathrm{pH} 7.5$ and $37^{\circ} \mathrm{C}$. Presence of different supplements may enhance or retard the decolorizing ability of consortium. When supplements were provided the consortium exhibited a remarkable increase in dye degradation and decolorization. The consortium decolorized 93, 94, 93,
94, and $89 \%$ of red, green, black, yellow, and mixed dyes within $24 \mathrm{~h}$, respectively, on supplementation with sodium chloride. These were maximum decolorization percentages shown by the consortium. Starch supplement did not affect the decolorization of dyes. Ammonium chloride and ascorbic acid also increased the decolorization. Similar results were reported by Moosvi et al. [25] and Saratale et al. [10]. This can be applied for decolorization and degradation of effluents at industrial scale.

The biodegradation of effluents by isolated bacteria may lead to generation of a variety of products. Therefore, it is imperative to study the toxicity impact of these degradation products on the life stages of crops so as to overcome yield reduction $[10,13]$. Phytotoxicity analysis of textile dyes indicated that germination of plant seeds and radicle and plumule length were affected. In contrast, biodegraded dyes showed good results and toxicity was significantly alleviated. The results indicated that decolorization was maximum at $100 \mathrm{ppm}$; there was decreasing trend of decolorization at more than $100 \mathrm{ppm} \mathrm{NaCl}$ concentrations. It showed linear decrease with increase in concentration; it might be due to role of salt in inhibition of reductase enzyme. Therefore the consortium was competent in decolorization of red, green, black, and yellow dyes between $50 \mathrm{ppm}$ and $400 \mathrm{ppm}$. The results of present study are in accordance with Wang et al. [15]. Results obtained with red, green, black, and yellow dyes and their degradation products are in agreement with results reported by Saratale et al. [10] and Phugare et al. [17]. For example, seeds of $P$. mungo and S. vulgare showed good seed germination in treated water and less plant growth 


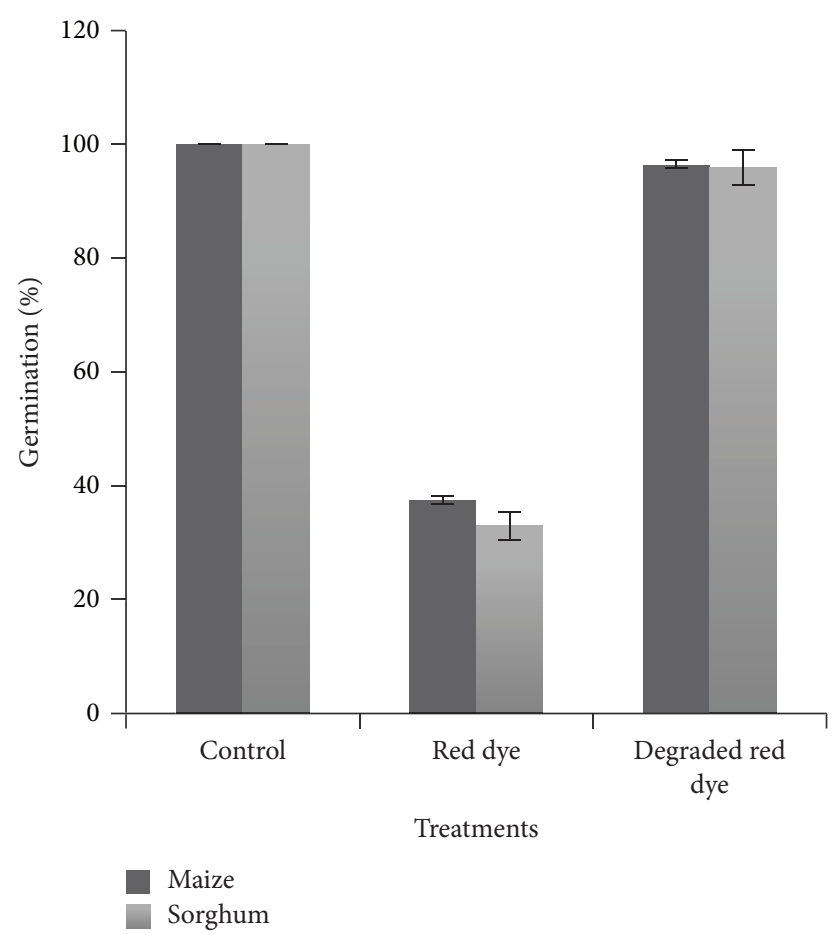

(a)

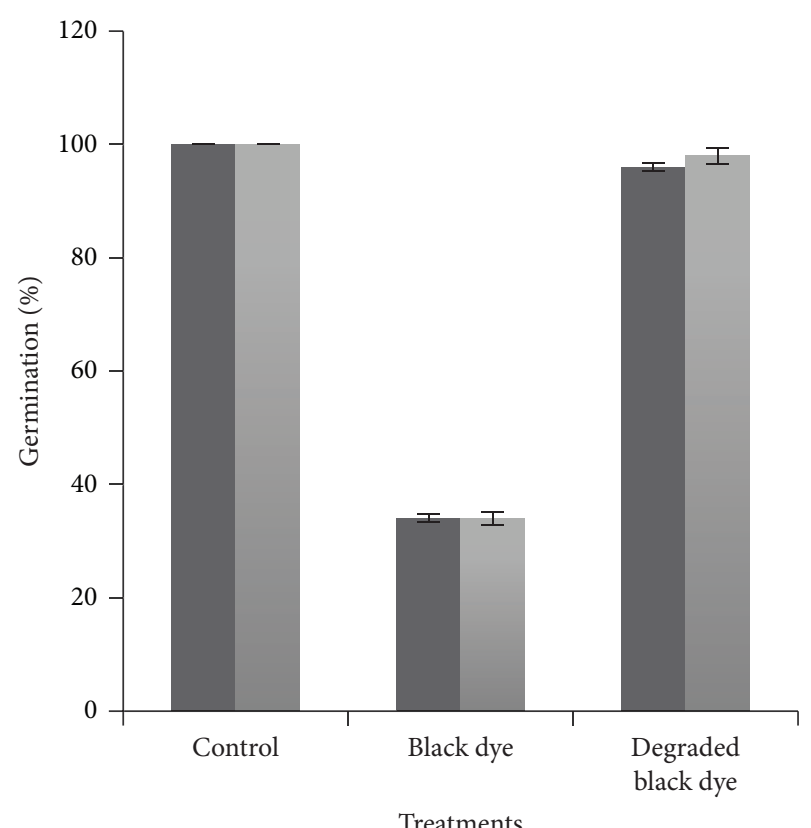

Maize

Sorghum

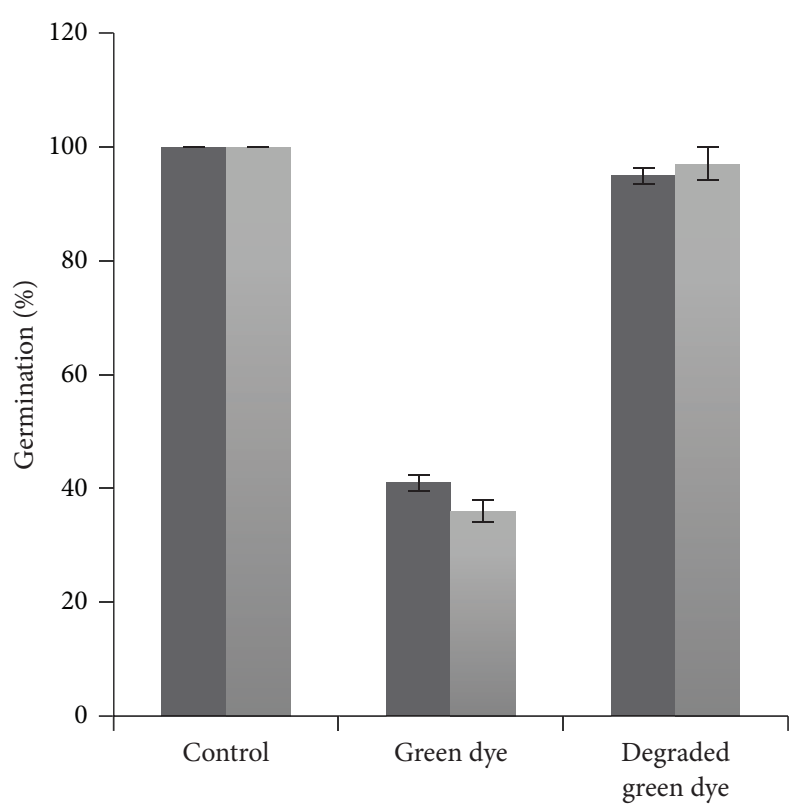

Treatments

Maize

Sorghum

(b)

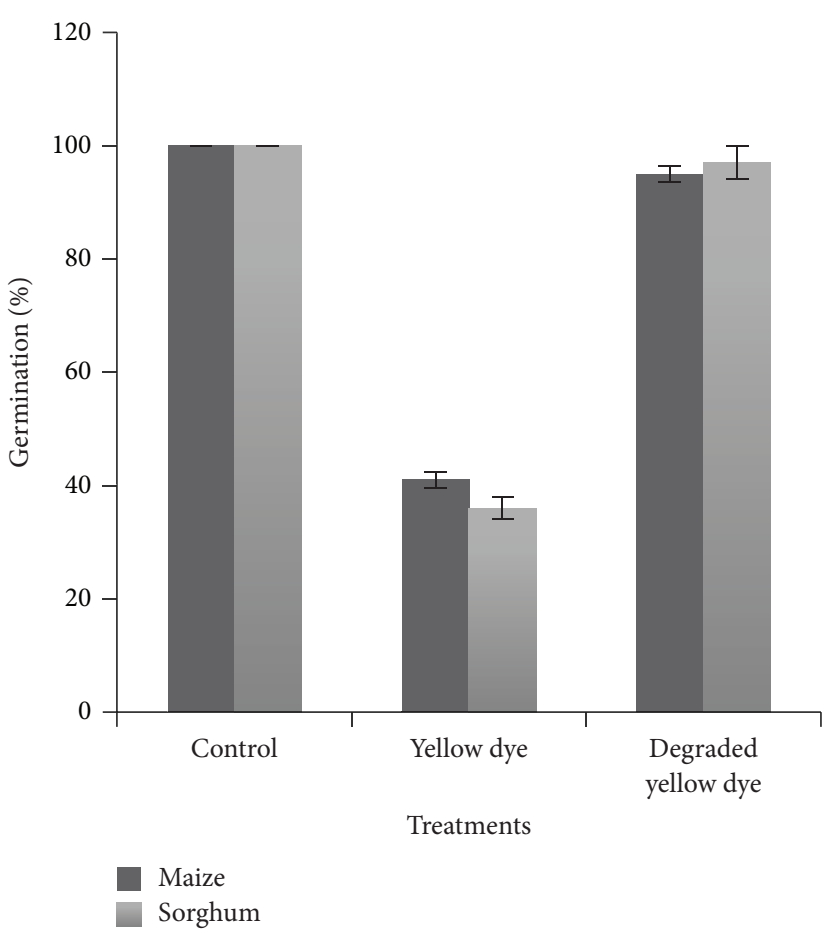

(d)

FIGURE 2: Effects of textile dyes: red (a), green (b), black (c), and yellow (d) before and after the degradation on germination of maize and sorghum.

in untreated wastewater [26]. The result indicated that the extracted degradation products by consortium give nontoxic products, resulting in good germination as well as plumule and radicle length of $Z$. mays and $S$. vulgare when compared to dyes. Toxicity of textile dyes is not restricted to plants only but the adverse effects of these have been reported [27] to mammals also. Exposure to these toxic textile dyes present in effluents and sludge can cause chromosomal 
alteration, DNA mutation, abnormal sperm, foetus loss, birth defects, and altered sex ratio in mammals. The treatment by bacterial consortium can be used effectively in reducing these adverse effects. As phytotoxicity studies revealed that the biodegradation of the red, green, black, and yellow dyes by the consortium led to detoxification of the pollutant, the bacterial consortium can be the best tool for the biotreatment of textile effluent.

\section{Conclusion}

A bacterial consortium BMP1/SDSC/01 consisting of six bacterial isolates (Bacillus cereus, Bacillus mycoides, Bacillus subtilis, Bacillus sp., Micrococcus sp., and Pseudomonas sp.) belonging to three genera exhibited good decolorization, degradation, and detoxification of red, green, black, and yellow dyes and mixture of all these dyes. The consortium BMP1/SDSC/01 has not been reported so far to our knowledge for dyes decolorization and degradation. The use of urea, sodium chloride, ammonium chloride, and ascorbic acid enhances the decolorization ability of consortium BMP1/SDSC/01. The water bodies used for irrigation purposes contain untreated effluent from dyeing industry. Thus, phytotoxicity studies on $Z$. mays and $S$. vulgare revealed that the biodegradation of the red, green, black, and yellow dyes by the consortium BMP1/SDSC/01 led to detoxification of the pollutant. Bioremediation gives an advantage for treatment of textile effluents and studies regarding the potential of consortium at large scale are in progress.

\section{Conflict of Interests}

The authors declare that there is no conflict of interests regarding the publication of this paper.

\section{Authors' Contribution}

This paper is a part of Rashid Mahmood's Ph.D. thesis performed under supervision of Faiza Sharif and Sikander Ali. Muhammad Umar Hayyat helped in the experimentation.

\section{Acknowledgments}

The work was carried out and completed at the Environmental Microbiology Division, Sustainable Development Study Centre, at Government College University Lahore. The authors gratefully acknowledge the centre for providing the necessary funding to carry out this research.

\section{References}

[1] P. Peralta-Zamora, C. M. Pereira, E. R. L. Tiburtius et al., "Decolorization of reactive dyes by immobilized laccase," Applied Catalysis B: Environmental, vol. 42, no. 2, pp. 131-144, 2003.

[2] A. Kunz, H. Mansilla, and N. Durán, "A degradation and toxicity study of three textile reactive dyes by ozone," Environmental Technology, vol. 23, no. 8, pp. 911-918, 2002.
[3] H. Wang, J. Q. Su, X. W. Zheng, Y. Tian, X. J. Xiong, and T. L. Zheng, "Bacterial decolorization and degradation of the reactive dye Reactive Red 180 by Citrobacter sp. CK3," International Biodeterioration and Biodegradation, vol. 63, no. 4, pp. 395-399, 2009.

[4] N. Daneshvar, D. Salari, and A. R. Khataee, "Photocatalytic degradation of azo dye acid red 14 in water on $\mathrm{ZnO}$ as an alternative catalyst to $\mathrm{TiO}_{2}$," Journal of Photochemistry and Photobiology A: Chemistry, vol. 162, no. 2-3, pp. 317-322, 2004.

[5] K. V. Kumar, V. Ramamurthi, and S. Sivanesan, "Biosorption of malachite green, a cationic dye onto Pithophora sp., a fresh water algae," Dyes and Pigments, vol. 69, no. 1-2, pp. 102-107, 2006.

[6] M. Sarioglu, U. Bali, and T. Bisgin, "The removal of C.I. Basic Red 46 in a mixed methanogenic anaerobic culture," Dyes and Pigments, vol. 74, no. 1, pp. 223-229, 2007.

[7] D. Deng, J. Guo, G. Zeng, and G. Sun, "Decolorization of anthraquinone, triphenylmethane and azo dyes by a new isolated Bacillus cereus strain DC11," International Biodeterioration and Biodegradation, vol. 62, no. 3, pp. 263-269, 2008.

[8] E. Forgacs, T. Cserháti, and G. Oros, "Removal of synthetic dyes from wastewaters: a review," Environment International, vol. 30, no. 7, pp. 953-971, 2004.

[9] N. Ali, A. Hameed, and S. Ahmed, "Physicochemical characterization and Bioremediation perspective of textile effluent, dyes and metals by indigenous Bacteria," Journal of Hazardous Materials, vol. 164, no. 1, pp. 322-328, 2009.

[10] R. G. Saratale, G. D. Saratale, D. C. Kalyani, J. S. Chang, and S. P. Govindwar, "Enhanced decolorization and biodegradation of textile azo dye Scarlet $\mathrm{R}$ by using developed microbial consortium-GR," Bioresource Technology, vol. 100, no. 9, pp. 2493-2500, 2009.

[11] K. Jain, V. Shah, D. Chapla, and D. Madamwar, "Decolorization and degradation of azo dye-reactive Violet $5 \mathrm{R}$ by an acclimatized indigenous bacterial mixed cultures-SB4 isolated from anthropogenic dye contaminated soil," Journal of Hazardous Materials, vol. 213-214, pp. 378-386, 2012.

[12] J. Mao, Y. Luo, Y. Teng, and Z. Li, "Bioremediation of polycyclic aromatic hydrocarbon-contaminated soil by a bacterial consortium and associated microbial community changes," International Biodeterioration \& Biodegradation, vol. 70, pp. 141-147, 2012.

[13] J. P. Jadhav, S. S. Phugare, R. S. Dhanve, and S. B. Jadhav, "Rapid biodegradation and decolorization of direct orange 39 (orange TGLL) by an isolated bacterium Pseudomonas aeruginosa strain BCH," Biodegradation, vol. 21, no. 3, pp. 453-463, 2010.

[14] J. Cheriaa, M. Khaireddine, M. Rouabhia, and A. Bakhrouf, "Removal of triphenylmethane dyes by bacterial consortium," The Scientific World Journal, vol. 2012, Article ID 512454, 9 pages, 2012.

[15] Z. W. Wang, J. S. Liang, and Y. Liang, "Decolorization of Reactive Black 5 by a newly isolated bacterium Bacillus sp. YZU1," International Biodeterioration and Biodegradation, vol. 76, pp. 41-48, 2013.

[16] S. S. Gomare, D. P. Tamboli, A. N. Kagalkar, and S. P. Govindwar, "Eco-friendly biodegradation of a reactive textile dye Golden Yellow HER by Brevibacillus laterosporus MTCC 2298," International Biodeterioration and Biodegradation, vol. 63, no. 5, pp. 582-586, 2009.

[17] S. S. Phugare, D. C. Kalyani, S. N. Surwase, and J. P. Jadhav, "Ecofriendly degradation, decolorization and detoxification of 
textile effluent by a developed bacterial consortium," Ecotoxicology and Environmental Safety, vol. 74, no. 5, pp. 1288-1296, 2011.

[18] APHA, Standard Methods for the Examination of Water and Wastewater, American Public Health Association, Washington, DC, USA, 2005.

[19] A. Kaur, S. Vats, S. Rekhi et al., "Physico-chemical analysis of the industrial effluents and their impact on the soil microflora," Procedia Environmental Sciences, vol. 2, pp. 595-599, 2010.

[20] J. G. Holt, N. R. Krieg, P. H. Sneath, J. T. Staley, and S. T. Williams, Bergey's Manual of Determinative Bacteriology, Williams \& Wilkins, Philadelphia, Pa, USA, 1994.

[21] B. D. Tony, D. Goyal, and S. Khanna, "Decolorization of textile azo dyes by aerobic bacterial consortium," International Biodeterioration and Biodegradation, vol. 63, no. 4, pp. 462-469, 2009.

[22] A. Zahoor and A. Rehman, "Isolation of $\mathrm{Cr}(\mathrm{VI})$ reducing bacteria from industrial effluents and their potential use in bioremediation of chromium containing wastewater," Journal of Environmental Sciences, vol. 21, no. 6, pp. 814-820, 2009.

[23] D. C. Kalyani, P. S. Patil, J. P. Jadhav, and S. P. Govindwar, "Biodegradation of reactive textile dye Red BLI by an isolated bacterium Pseudomonas sp. SUK1," Bioresource Technology, vol. 99, no. 11, pp. 4635-4641, 2008.

[24] J.-L. Han, I.-S. Ng, Y. Wang et al., "Exploring new strains of dyedecolorizing bacteria," Journal of Bioscience and Bioengineering, vol. 113-114, no. 4, pp. 508-514, 2012.

[25] S. Moosvi, X. Kher, and D. Madamwar, "Isolation, characterization and decolorization of textile dyes by a mixed bacterial consortium JW-2," Dyes and Pigments, vol. 74, no. 3, pp. 723729, 2007.

[26] A. N. Kabra, R. V. Khandare, and S. P. Govindwar, "Development of a bioreactor for remediation of textile effluent and dye mixture: a plant-bacterial synergistic strategy," Water Research, vol. 47, no. 3, pp. 1035-1048, 2013.

[27] H. I. Soni, P. P. Bakre, and P. Bhatnagar, "Assessment of teratogenecity and embryotoxicity of sludge from textile industries at Pali (India) in Swiss albino mice exposed during organogenetic period," Journal of Environmental Biology, vol. 29, no. 6, pp. 965969, 2008. 

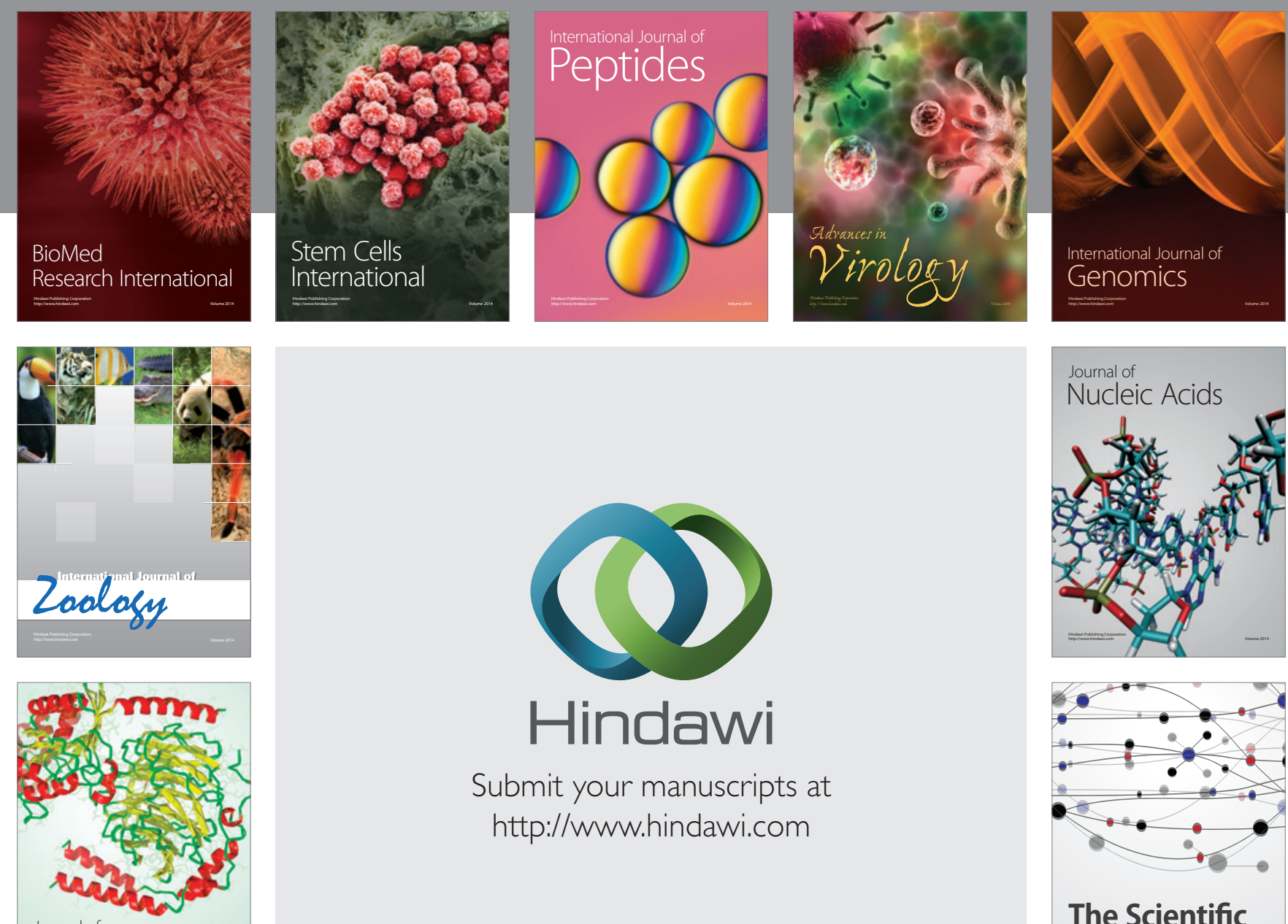

Submit your manuscripts at

http://www.hindawi.com

Journal of
Signal Transduction
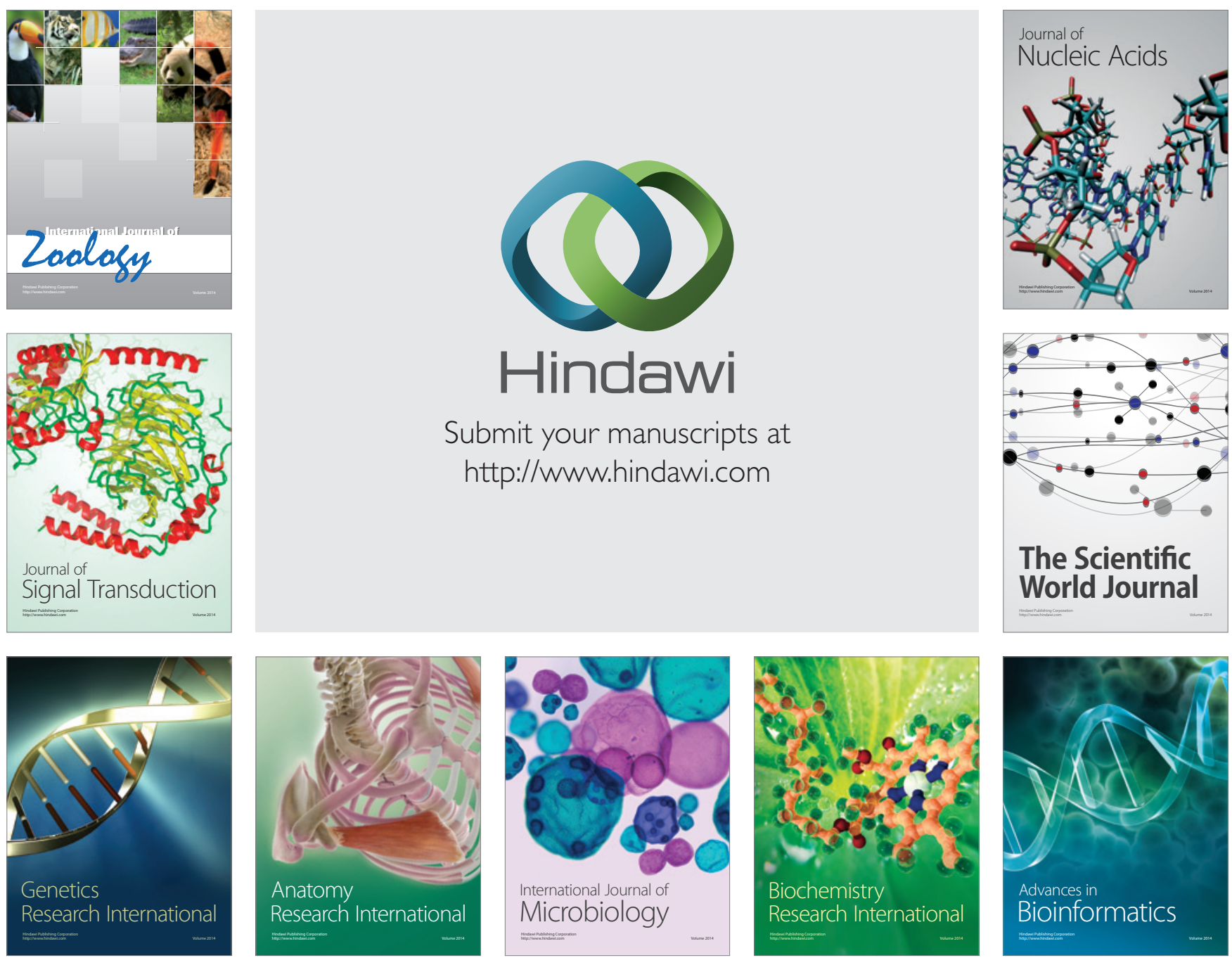

The Scientific World Journal
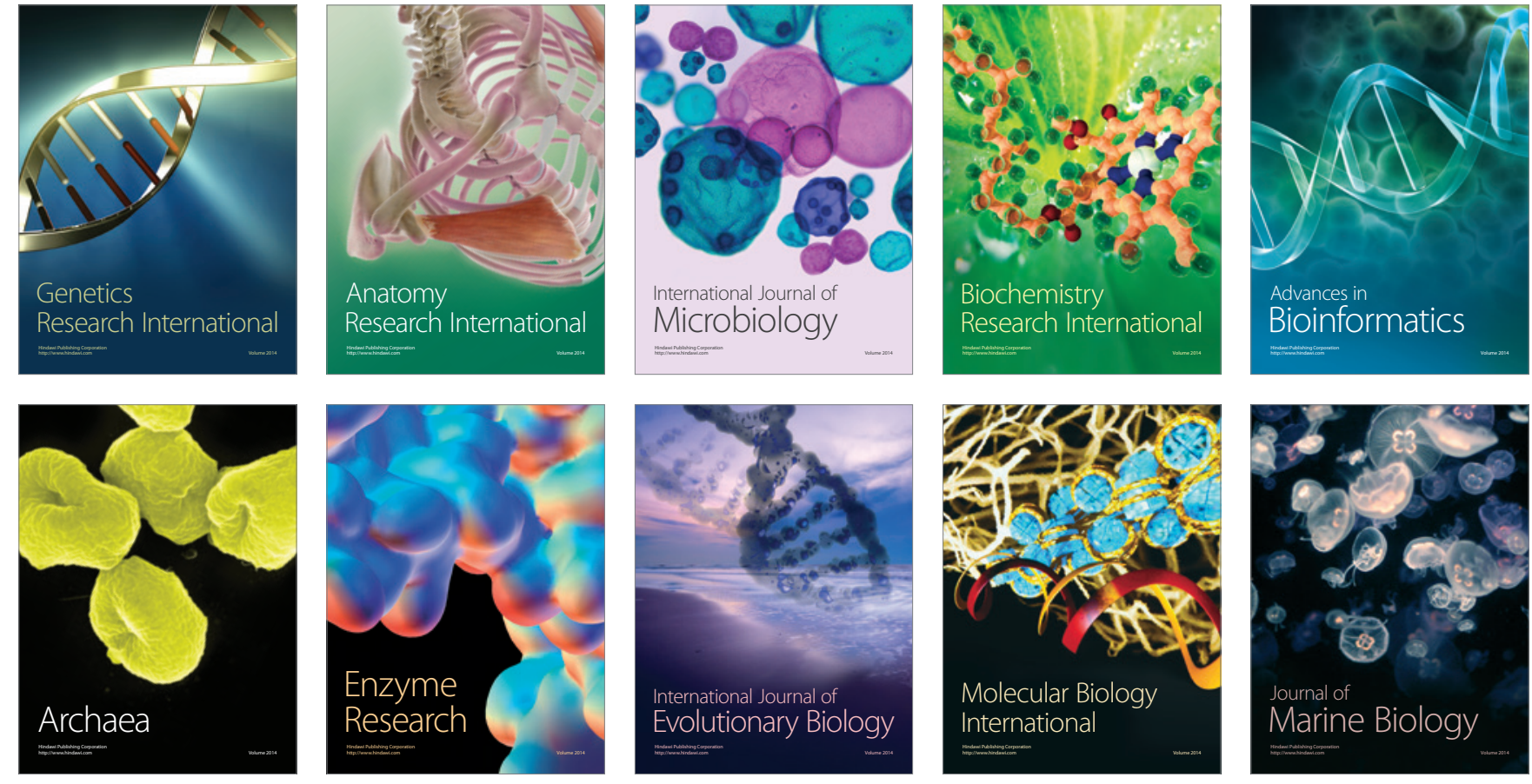